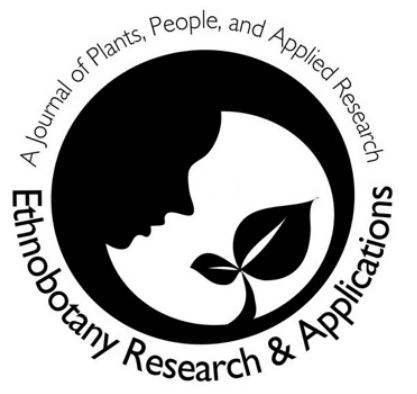

\section{What to conserve? Different contexts/different pretexts: three study cases in Argentina}

María Belén Doumecq, Daniela Alejandra Lambaré, Pablo César Stampella

\author{
Correspondence \\ María Belén Doumecq ${ }^{\star 1,2}$, Daniela Alejandra Lambaré1,3, Pablo César Stampella ${ }^{1,2}$ \\ ${ }^{1}$ Consejo Nacional de Investigaciones Científicas y Técnicas, Argentina. \\ ²Laboratorio de Etnobotánica y Botánica Aplicada (LEBA), Facultad de Ciencias Naturales y Museo, Universidad \\ Nacional de La Plata, Argentina \\ ${ }^{3}$ Grupo de Etnobiología y Micrografía Aplicada, Instituto de Ecorregiones Andinas (INECOA, UNJu-CONICET), San \\ Salvador de Jujuy, Argentina. \\ *Corresponding Author: mbelendoumecq@gmail.com \\ Ethnobotany Research \& Applications 22:33 (2021)
}

\title{
Research
}

\begin{abstract}
Background: The starting point of this work is Alcorn's definition of ethnobotany. For this reason, the author goes on to say that the ethnobotanical study object is a sort of text -sensu Ricoeur (1971 cited Alcorn 1995)- whose meaning is partially derived from the natural, social- and cultural context. Following this perspective of conservation, the goal of this contribution is to analyze the significance of three tree taxa populations in three areas of Argentina.
\end{abstract}

Methods: Ethnobotanical and historical ethnobotany methodology have been used.

Results: The Quebrada peach (Prunus persica), early introduced to Jujuy province, assimilated into local crops, and considered as part of local identity. Various citrus (Citrus spp.), also introduced early on by the Jesuits, and highly valued by the locals in Misiones, but rejected in the management of protected areas due to their wild-type and exotic nature-. The tala (Celtis tala), native to the Río de la Plata coastal area, where it lends its name to a particular forest formation, which is often overexploited, and is the focus for the establishment of protected areas.

Conclusions: The perusal of these texts (tala, peaches, and citrus) demonstrates that they are considered as a part of local identity or heritage no matter a long or short story and native or exotic origin. We also to contribute to the design of conservation strategies from a biocultural perspective.

Keywords. Identitary species, Immaterial heritage, Introduction of plants, Landscape construction, Local practices, Perceptions, Qualitative ethnobotany.

\section{Background}

The starting point of this work is Alcorn's (1995: 24) definition of ethnobotany as "the study of plant human interrelationships embedded in dynamic ecosystems of natural and social components. Put another way, it is the study of contextualized plant use". Both the use of plants and other human-plant interrelationships are shaped by history, by their physical and social environments, and by the qualities inherent to the plants themselves. For this 
reason, the author goes on to say that the ethnobotanical study object is a sort of text - sensu Ricoeur (1971 cited Alcorn 1995)- whose meaning is partially derived from the natural, social and cultural context.

The idea that human activity is antagonistic to the environment (which should be preserved through diverse mechanisms, generally imply intangibility), has become established in diverse contexts, and particularly in those responsible for decision-making, therefore giving rise to the conservation paradigm (Evans 1993). This model of intangibility also translates into contempt for exotic species. However, this conception ignores the role of local people in biocultural conservation, since many of the landscapes that are intended to be preserved are the result of traditional human activities and/or practices (eg, slash and burn, tolerance, protection, agriculture) generating changes in the environment (Hilgert et al. 2014, Hurrell et al. 2019, Stampella 2018). More recently, conservation through use has been proposed, which states that taking advantage of available resources tends to value and conserve them rather than their elimination (Evans 1993). Thus, the conservation of biological diversity cannot be separated from cultural memory and local botanical knowledge (Nazarea 2006). In fact, for local people, diversity is the sum of biological and cultural diversity, for them there is no such division, both components co-evolve inseparably (Diegues 2000, Maffi 2001). From the recognition of local people as effective administrators of biodiversity and landscape modeling, Biosphere Reserves emerge that contemplate human occupation and sustainable development, however, in their management, the native / exotic dichotomy remains, and efforts are focused on the conservation of native species (Doumecq et al. 2020).

This dichotomy was also important in ethnobotanical studies. Whereas the early ethnobotanists dismissed the exotic species that were mentioned by social actors because they did not consider the knowledge about them as genuine, in recent times the view of these plants has been revised and has allowed the proposal of a radical change of perspective (Ladio 2005, Lambaré 2015, Martínez \& Manzano-García 2016, Medeiros et al. 2017, Stampella 2015, Villalba \& Lambaré 2019). Nevertheless, those in charge of environmental management decisions often maintain a negative view of introduced species, both wild and cultivated.

Also, the valuation that local people have for introduced species has often been disregarded. However, the decision whether to incorporate exotic elements can only be understood in the context of the practices, lore, and beliefs of each group, which are in continuous transformation, and with the social actors taking active part in the decisions to conserve, incorporate, reject, or abandon customs and objects within their social and historical dynamics (Lambaré \& Pochettino 2012).

In this sense, the objective of this contribution is to analyze the meaning of three tree taxa for local people in three areas of Argentina. We discuss similarities and differences to assess the importance of context in shaping that meaning. It is worth noting that those taxa are under some degree of environmental protection and that locals play an active role in their conservation. The tree species are: 1- "Quebrada peach" [Prunus persica (L.) Batsch] from Humahuaca Ravine (Quebrada de Humahuaca, Jujuy province), introduced during the colonial period; 2- citrus trees [Citrus spp.], also introduced early on by Jesuits (Misiones province) and 3- tala [Celtis tala Gillies ex Planch.], a small tree native to the coast of the Río de la Plata river, where it gives its name to the talares (hence talar forests) low forest formations typical of this coastal sector (Buenos Aires province).

\section{Material and Methods \\ Study area}

For this research, we selected three areas of Argentina with cultural, historical and phytogeographical differences, which share the fact that they are under some level of environmental protection: 1) Juella, a community located in the north of Tilcara department, in Humahuaca Ravine "Quebrada de Humahuaca", Jujuy province (UNESCO World Heritage Site since 2003); 2) Cerro Mártires, a locality northeast from Concepción de La Sierra department, in the south of Misiones province (Ruins of "Santa María la Mayor" and its forest); and 3) the area of influence of the "Parque Costero del Sur" (hence PCS) Biosphere Reserve, which includes the coastal sector of the departments Magdalena and Punta Indio, in north-eastern Buenos Aires province (Fig. 1).

The community in Juella includes peasant farmers descended from native populations and European settlers, dedicated to agriculture since prehispanic times (Lambaré 2015). Some of the interviewees combine farming with jobs in the municipal government. Their major products include both pome and stone-fruits, maize, potatoes (Solanum tuberosum L. subsp. andigenum (Juz. \& Bukasov.) Hawkes), fava beans (Vicia faba L.), as well as goat cheese and goat and cow meat. In phytogeographical terms, this place is part of the valleys of the Prepuna Province, in the Chacoan Domain (Cabrera 1971) and within Humahuaca Ravine, which is a World Cultural Heritage site. 


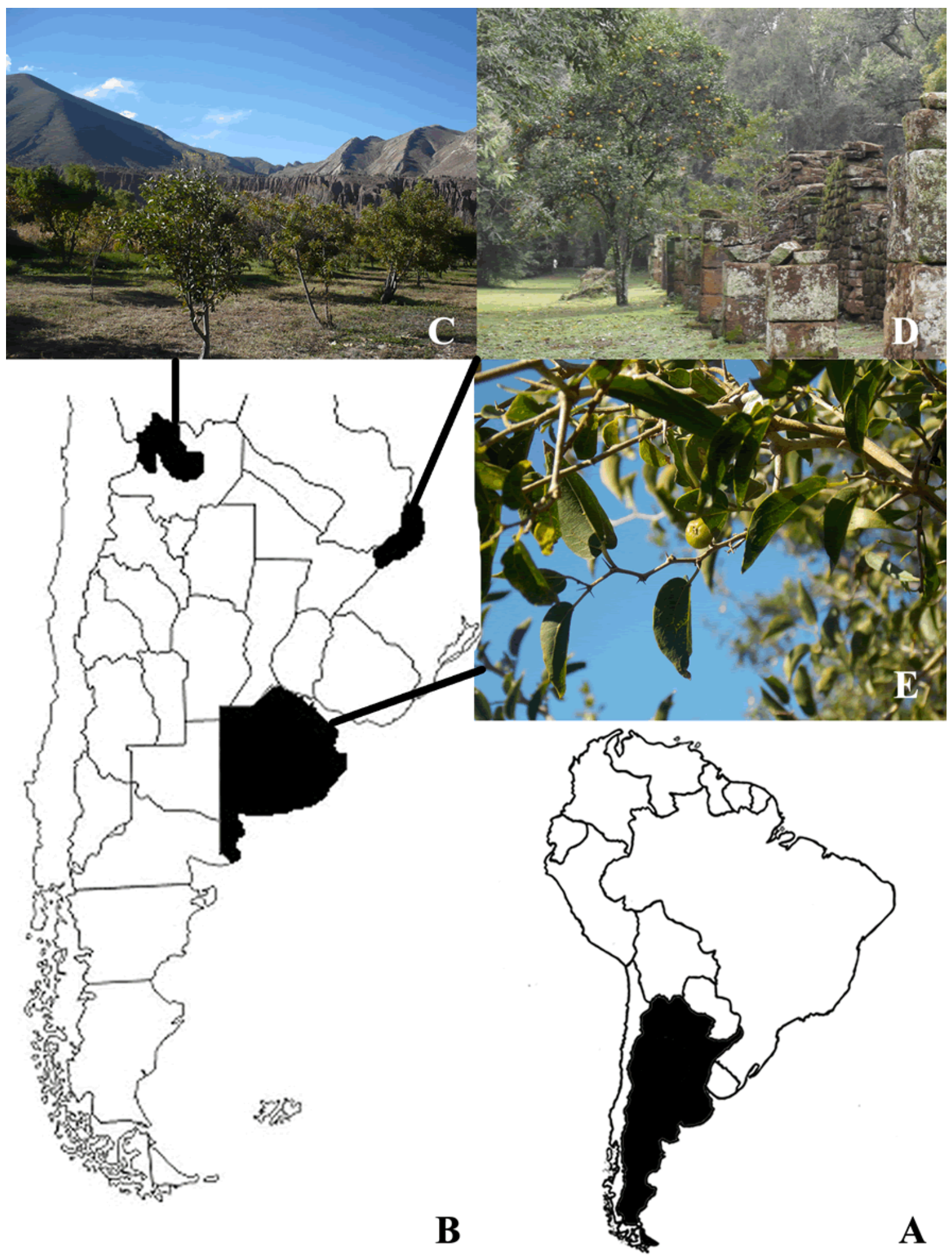

Figure 1. Study area and studied species. A. Location of Argentina in South America (in black). B. The three provinces involved in the study (in black). C. Peach trees ( $P$. persica) in a rastrojo (crop field). D. Specimen of apepú (Citrus $\times$ aurantium) in Jesuitical ruins of Misiones. E. Detail of a branch of Celtis tala with fruits.

The second locality, Cerro Mártires, is a small place located along Provincial Route $N^{\circ} 30$ that connects Paraje La Corita with Arroyo del Medio, in the vicinity of a $18^{\text {th }}$ century Jesuit reduction for the Guarani ("Santos Mártires del Japón"); and 12 km away from the Jesuit ruins of Santa María la Mayor (UNESCO Heritage Site). This zone is near the Parque Costero del Río Uruguay Route (Provincial Decree $N^{\circ}$ 1373). The locals -descended from M’bya and 
from 20th century European settlers- relay on slash-and-burn agriculture and cattle farming, which they complement with hunting, fishing, and gathering of various plants. The production units are known as "chacra" (small farm) and the production is used both for subsistence and eventually for sale or exchange of surplus. The main crops are sugarcane (Saccharum officinarum L.), manioc (Manihot esculenta Crantz), beans (Phaseolus spp.) and maize (Zea mays L.) (Stampella 2016, 2018). From a phytogeographic perspective, this site is within the Urunday District, a transitional zone between the Mixed Forests and the Fields districts, all of which belong to the Paranensean Province (Cabrera 1971, Martínez-Crovetto 1963).

Lastly, the PCS Biosphere Reserve is part of the Eastern Pampean District, Pampean Province (Cabrera \& Willink 1980), and its inhabitants, highly diverse in terms of provenance, are distributed in urban, periurban and rural nuclei. The main economic activities in this region are seashell mining, extensive cattle farming (Arturi et al. 2009) and tourism in one locality, Punta del Indio. The main use of plants, both past and present, is extraction for firewood, both in local homes and for commercial purposes.

\section{Ethnobotanical methods}

To achieve this contribution, we put into dialogue our doctoral thesis, performed in the above-mentioned areas. Consequently, different strategies have been employed. Both historical and actualistic ethnobotanical methodology have been used. Historical ethnobotany is the diachronic analysis of documentary sources for understanding past interrelationships between people and plants (Hernández Bermejo \& Lora González 1996, Medeiros 2010, Touwaide 2010), in this case the introduction of exotic fruit trees. Documentary sources, conceived in a wide sense (including written literature, unpublished documents and chronicles, iconography, maps, photographs, cadastral references) have been identified, recorded, analyzed and criticized (Medeiros 2010). We have also considered archaeobotanical literature to establish Celtis tala antiquity of use (Pérez Meroni et al. 2010).

The first stage in actualistic study was obtaining the prior informed consent from all interviewees; in this procedure they were told about the characteristics of the research, the dissemination and expected return of the results (Laird \& Noejovich 2002). Field work was done between 2010 and 2019, using a qualitative ethnobotanical methodology involving diverse ethnographic techniques, such as open and semi-structured interviews, participant observation, walks and participant workshops (Cotton 1998), to characterize local beliefs, knowledge and practices regarding the tree species studied. We worked with 64 local inhabitants from the three areas of Argentina (Jujuy, Misiones and Buenos Aires). In Juella, Jujuy province, the work involved 30 producers (19 women and 11 men) between 43 and 77 years. The inhabitants of these high arid valleys are farmers dedicated to crop and cattle farming for selfconsumption and local commerce. The study in Cerro Mártires (Misiones) involved a total of 11 interviewed, 6 males and 5 females, between 18 and 80 years, nine of which were visited repeatedly. Their occupations spanned crop farmers ("chacrero"), cattle farmers, employees (forestry, cattle), and some that also took casual jobs. In the PCS area, we worked with 23 interviewed ( 6 women and 17 men), between 45 and 75 years. These individuals had diverse occupations, ranging from farming, commerce, hired workers, municipal employees and officials, and retirees (pensioners).

The plant material for reference was collected in the company of the corresponding interviewed at diverse sites that they identified. This plant material was later prepared, taxonomically determined and deposited in the collections of the Laboratorio de Etnobotánica y Botánica Aplicada (FCNyM, UNLP) and INECOA (UNJU-CONICET). The cultural, spatial and temporal contextualization allows the use of terms such as "ethnotaxa" -singular "ethnotaxon"-, "ethnospecies" and "ethnovariety" to define the locally recognized variability or discontinuities between species, and cultivated and wild varieties (Harlan 1992, Rivera-Núñez et al. 1997).

The field work was complemented by means of eight interviews to people involved in the management of protected areas (this included Tourism officers of the municipalities of Humahuaca Ravine, forest rangers, members of the management committee in the case of PCS, guides and staff employed in the Jesuitic ruins), as well as governmental documents and publications, in order to contrast their opinions and appraisals with those of the local population.

In agreement with Taylor et al. (2016) we consider that qualitative data analysis is an intuitive and inductive process. Consequently, we performed our own analysis and codification of the data, to gain a deeper understanding of what we have recorded in the field and to continually refine our interpretations. For that reason, data analysis was an ongoing process and went hand to hand with data collection. As we were working with local narratives, the main steps were: identifying themes, reviewing and comparing data, collecting additional data, elaborating the final concept. 


\section{Results and Discussion}

Table 1 shows a comparative ethnobotanical characterization of the studied species in the contexts considered for this work.

Table 1. Comparison of different features of peaches, citrus and tala in the considered contexts

\begin{tabular}{|c|c|c|c|}
\hline Ethnotaxon & Peaches & Citrus fruits & Tala \\
\hline Origin & China & Southeast Asia & $\begin{array}{l}\text { America, from North } \\
\text { America to central-south } \\
\text { South America }\end{array}$ \\
\hline History & $\begin{array}{l}\text { Early introduction. } \\
\text { Second half of } 16^{\text {th }} \\
\text { century }\end{array}$ & $\begin{array}{l}\text { Early introduction to America, } \\
\text { introduced locally by Jesuits at } \\
\text { the start of the XVII century }\end{array}$ & $\begin{array}{l}\text { Native. Associated with } \\
\text { indigenous groups since } \\
\text { the late Holocene, } \\
\text { Intensive use of talar } \\
\text { forests in colonial times }\end{array}$ \\
\hline Current use & $\begin{array}{l}\text { Food (fruit), medicinal } \\
\text { (juice of desiccated } \\
\text { peaches), Fuel (firewood), } \\
\text { fertilizer (epicarp } \\
\text { removed from the fruits), } \\
\text { as graft foot (branches) }\end{array}$ & $\begin{array}{l}\text { Food: fruit, juice. Bait for hunting } \\
\text { and fishing. Seasoning. Preserves } \\
\text { and jams. Alcoholic drinks. Cattle } \\
\text { fodder. Medicinal (multiple } \\
\text { ailments). Ornamental. As } \\
\text { container for "tereré" (cold } \\
\text { herbal infusion) }\end{array}$ & $\begin{array}{l}\text { Fuel (firewood and coal), } \\
\text { tool handles, food (fruit, } \\
\text { jams, liquors), dyeing and } \\
\text { medicinal. Shade and } \\
\text { shelter for livestock. }\end{array}$ \\
\hline Local practices & $\begin{array}{l}\text { Cultivation: } \\
\text { Fertilizer, pruning and } \\
\text { selection of seeds. }\end{array}$ & $\begin{array}{l}\text { Gathering and in situ } \\
\text { consumption. Tolerance to wild } \\
\text { plants when Domestic Unit (DU) } \\
\text { moves further the forest. } \\
\text { Fostering by bringing saplings } \\
\text { from natural forested areas. } \\
\text { Protection and cultivation (sensu } \\
\text { stricto) in diverse } \\
\text { microenvironments of the DU } \\
\text { (gardens, fruit tree copse, } \\
\text { vegetable plot, fields, slash-and- } \\
\text { burn, capuera forest, forest) }\end{array}$ & $\begin{array}{l}\text { Eradication. Pruning of } \\
\text { leaves and branches. } \\
\text { Gathering, in situ } \\
\text { consumption. Tolerance, } \\
\text { fostering, conservation. }\end{array}$ \\
\hline Public policies & $\begin{array}{l}\text { Ethnovarieties are } \\
\text { preserved and } \\
\text { commercialized (fruit and } \\
\text { processed products) at } \\
\text { local scale. No public } \\
\text { policy for their } \\
\text { protection, but this crop } \\
\text { is perceived as being } \\
\text { typical/characteristic for } \\
\text { the area. }\end{array}$ & $\begin{array}{l}\text { Commercial varieties cultivated } \\
\text { as mono- and polyculture. In } \\
\text { protected areas citrus plants are } \\
\text { removed due to their being } \\
\text { exotic species. }\end{array}$ & Protected species \\
\hline
\end{tabular}

History of the "Quebrada peaches" ("duraznos de la Quebrada")

According to available bibliographical records, the origin of this species was in the mountain areas of Tibet and northern China. Its presence in the Mediterranean region goes back to the beginnings of the Christian Era ( $1^{\text {st }}$ century); however, its taxonomy, evolutionary history, and centers of origin and dispersal, are still being debated (Burger et al. 2011, Burkart 1972, Delucchi 2011, Depypere et al. 2007). Pip and stone fruits of the rose family (Rosaceae) first entered the Argentine Northwest during the second foundational (second half of $16^{\text {th }}$ century) 
journey into what is currently part of the province Santiago del Estero, and subsequently expanded their range during the second half of the century with the founding of cities in Tucumán, Salta and Jujuy (Sica 2010). These expeditions were driven by diverse motives; on the one hand, the need to find new lands to cultivate using native labor (recreating Spanish-style farming environments, a task that was not possible in the highlands due to the high population density) and on the other, to establish a connection between the Central Andes and the Northwest, particularly with the "Gobernación del Tucumán" (Sica \& Ulloa 2010). Even though these crops were not part of the daily diet of native peoples according to archaeological records, between the second half of the $16^{\text {th }}$ century and the beginning of the $17^{\text {th }}$ century these species were already being handled and incorporated (Báez 1947, 1949, Capparelli et al. 2005), possibly having been stolen from or discarded by frustrated expedition teams (Sica et al. 2010). By the end of the $17^{\text {th }}$ century, the colonial system was firmly established in the region of Tucumán. In that context, the territory of the current province of Jujuy (extreme northwestern Argentina) was considered during the colonial period as a transit/border zone, used by both the native population and the Spaniards as a route to reach Bolivia (Potosí) and Perú (Lorandi 1988). European products were incorporated early on, beginning with episodes of coexistence/cohabitation in Spanish settlements -which were later abandoned- and with the contact resulting from the travel of Europeans between the southern high lands and the Gobernación de Tucumán further to the north (Sica 2006). Vázquez de Espinosa describes Humahuaca Ravine in the mid-17th century: "...Omaguaca es pueblo de indios, el valle es fértil, y abunda el trigo y maíz, papas, con otras raíces y frutas de españa y la tierra esta toda poblado de pueblos pequeños de indios..." ["...Omaguaca is a settlement of indians, the valley is fertile, with abundant wheat and maize, potatoes, with other fruit and root vegetables from Spain, and the land is entirely populated with small Indian villages..."] (Sica 2006, Chap. 6: 6). The same author (2006, Chap. 6: 5) transcribes a narration by Sotelo de Narváez regarding the Calchaqui Valleys in 1580, before the definitive foundation of Jujuy, as follow: "...hay muchas crias de yegua, vacas, mulas, ovejas y cabras y puercos en abundancia; de todo lo cual tienen los indios y los crian como españoles... Cogese en esta tierra trigo y maiz, cebada y mucha cantidad de frisoles y dasé todo lo de Castilla, por la experiencia que se tiene de haber estado en esta tierra poblado un pueblo de españoles...". ["... there is much breeding of mares, cows, mules, sheep and goats and abundance of pigs; all of these the Indians have and raise them in the Spanish style... in this land the crops yield wheat and maize, barley and many beans, and everything grown in Castilla, because in the past a settlement of Spaniards existed in this land..."]

The joint presence of peach trees and Andean crops, which are arranged following specific patterns of distribution and with crop cycles adjusted to fit them, highlights the long tradition behind these practices. With respect to environmental requirements, peach trees are characteristic of temperate zones, they require cold rainy winters coupled with arid springs, hot dry summers, and temperate-cold autumns; these trees need an accumulation of winter cold for successful budding. Likewise, they are sensitive to strong winds (Scorza \& Sherman 1996). Similar environmental conditions in the zone allow assuming that in the case of the Quebrada peaches, in spite of having a different rain regime (with summer rains), the conditions were favorable and their cultivation became adjusted to the local temporality, i.e. they gave rise to a crop that is managed with a cycle similar to those of species of Andean provenance, such as maize.

The most important perceived role of the fruit for the local population is as food: "I have known it is important to my life. In my memories they are the favorites because they not only fed me, when I was a teenager, they helped me with my studies, because dad would take them to Ledesma (department of Ledesma, Jujuy) and sell them"(M.F., 73 year old, female, Juella).

The fruits are eaten fresh, desiccated or as part of diverse preparations (jelly, marmalade, or jam). As a medicinal option, the juice of desiccated peaches (pelones) boiled with sugar ("compota") is used to treat kidney-related ailments. Likewise, during the pruning season for peach trees (June-July), secondary shoots ("chupones") and lateral non-blossoming branches are removed and used for firewood or grafted onto a different graft foot. After the harvest, the women peel the ripe peaches to make pelones, and the epicarp removed from the fruits is deposited on crop soils as fertilizer (Lambaré 2014).

The ethnovarieties included in the ethnotaxon Quebrada Peach or Juella Peach are primarily classified into common peaches and "prisco" peaches, which differ in the adherence between the "stone" (fruit endocarp) and the "flesh" (fruit mesocarp). Within these two groups we were able to identify nine ethnovarieties defined by particular attributes or features -of the fruit and/or other plant parts- recognized by the farmers in the community. These attributes are defined by use, some agronomical characteristics, and personal assessment. 
Peaches play an important role in the food heritage of the area, and both the fresh fruits and the manufactured fruit products are offered as typical products. They are sold in commercial shops for tourists but are also the focus of theme fairs that involve the local population (Lambaré et al. 2015). All these activities are promoted by management officers in the diverse localities of the area, who recognize "gastronomic tourism as an economic alternative to promote local products in the different communities in the area" (C.M., 46 year old, male, Humahuaca) according to to the reports from members of the Tourism Secretary Offices of those municipalities. Therefore, peaches become a differential product that boosts local economies. Thus, even though there are neither specific policies for the protection of peaches as a local crop, nor plans for their eradication as foreign species, in actual fact the cultivation of this species is implicitly promoted through encouragement of its consumption.

\section{History of apepú and other citrus fruits in south Misiones}

Citrus trees are native to the warm regions of Southeast Asia, temperate areas of China, Australia and southwestern Pacific islands (Gmitter \& Hu 1990). Since the 11th century, Arabian travelers took citrus from India to the coasts of the Mediterranean Sea. The Spanish and Portuguese people brought them to America during the conquest and these plants became established in the area that currently corresponds to Misiones province due to the actions of Jesuits in the early 17th century (Hilgert et al. 2014, Ramón-Laca 2003, Stampella et al. 2013a). Currently, five citrus taxa occur spontaneously in Argentina (Hurrell et al. 2010, Seo \& Xifreda 2008, Stampella et al. 2013a, 2014).

This early entrance was not a uniform process, but rather signaled the starting point of the arrival of diverse varieties, which entered Argentina as pulses with different paths and provenances. Those first varieties brought to the Spanish colonies in Asunción and surroundings were joined by others introduced by the Jesuits during the 150 years of permanence of their missions. Although there are no details regarding citrus trees in the written works of Jesuits that lived near the studied location, it is possible to transpolate the diversity portrayed in the "Treatise on Citrus" by the Italian Jesuit Ferrari (1646), which dealt with grafted as well as "common" and "wild" plants. Similarly, the inventories written by Brabo (1872) for the expulsion of Jesuits in 1768 provide a brief account of the standing plants that remained in their orchards. The beginning of citrus cultivation in the Argentine Northeast (NEA) and the search for novel graft supports with greater resistance to diseases and the novel climatic and soil conditions led to the entrance of local varieties imported from Africa, India, and Australia (Banfi 1954, Palacios 1978).

This introduction of varieties with disparate levels of dependence on humans may be seen today in "criollo" (i.e., creole or local people) farming communities of south Misiones. At the abovementioned sites we recorded 30 ethnovarieties structured into nine ethnospecies, which in turn correspond to three groups of ethnovarieties according to their usage for grafts: common (cultivated from seeds, corresponding to the homonymous varieties of Ferrari), grafted (on diverse supports), and those used as graft foot (common varieties that were introduced relatively late and used as graft supports by the citrus production industry). In turn, this diversity comprises seven microenvironments or areas characterized by the presence of citrus trees: gardens (ornamental and medicinal plants), vegetable plots (cultivation of vegetables, spices and medicinal plants), fruit groves (plot with perennial fruit trees), fields, fire-fallow (slash-and-burn agriculture for maize, manioc, sugar cane, sweet potato), "capueras" (succession on abandoned farmlands) and forest (primary and secondary humid forest). The first three types are peridomiciliary areas with controlled management conditions, with predominance of grafted varieties as well as common varieties grown from seed or taken from the forest. The fire-fallow areas include both common and grafted varieties, which are tolerated when this productive microenvironment advances onto the forest. The "capueras" comprise the remains of abandoned productive microenvironments as well as common and grafted varieties newly grown due to the scarce plant cover. The forest hosts diverse "spontaneous" citrus varieties such as sweet orange and apepú (both Citrus $\times$ aurantium $\mathrm{L}$.), tangerine $(C$. reticulata Blanco) and lemon $(C$. $\times$ taitensis Risso), and occasionally sweet lime $(C . \times$ limettioides Tanaka) and grapefruit $(C . \times$ aurantium); these man-made forests are true reservoirs of an agro-diversity that is constantly under selection by the farming communities.

The close relationship between the local communities and citrus trees is also realized in the diversity of uses given to these plants. At local level, their alimentary uses include consumption as fruit (endocarp or pulp), elaboration of refreshing beverages (such as "tereré", widely consumed in the area); the whole fruits or their peel are used to make jams and preserves, and both the endocarp and epicarp as flavoring for cakes and alcoholic beverages. In addition, the juice obtained from sour-endocarp varieties is used as food seasoning. Their medicinal use is widely spread, with common varieties of most ethnospecies being used for the treatment and prevention of diverse diseases. Other less frequent uses include the use of hollowed-out fruits as containers for medicinal "mate" and "tereré", as 
ornamental trees and to provide shaded areas for cattle, and as bait for hunting small mammals and capturing fruit-eating fishes.

This perspective that corresponds to the local actors (in this case, "criollo" farmers) is complemented by other perceptions often related to larger-scale land holdings, such as those of cattle breeders and producers of yerba mate, other crops, and forestry (logging), which generally support agroecosystems that are less diverse and more dependent on external input, and where productive microenvironments are abundant in detriment of native forest.

The management practices (sensu Casas 2001) used by local communities for citrus plants are characterized by tolerance, favoring and protection (Stampella 2018): "when we clean a "rozado" (slash and burn) to plant or to build the house, we leave the seedlings that we find and even add forest soil and other fertilizers. We also take care of the animals that are going around the house or by the "rozado" (S.F., 70 years old, female, Cerro Mártires). When the above-mentioned microenvironments advance over the "monte" (native forest), those species considered useful -including citrus- are tolerated and remain as part of the domestic environment. These same plants are subsequently favored (by dispersion of propagules or elimination of competitors) and often protected (by pruning and/or protection against pests). A similar process occurs in the area of the Jesuit ruins categorized as UNESCO heritage (San Ignacio Miní, Santa Ana, Loreto and Santa María la Mayor) where the staff in charge of the maintenance of open spaces tolerates and protects citrus trees -as well as other useful plants- while performing maintenance in the estate parks. In contrast, the situation in protected areas is the complete opposite. The testimonies of park rangers indicate that these fruit trees are removed because they are exotic species: "We remove all the plants and seedlings that we find because they are exotic plants. We only leave one o two plants to have fruits to eat and prepare tereré (cool drink made with yerba mate and fruit juices)" (G.S. 45 years old, male, San Ignacio). Furthermore, some authors (Pedersen 1995) categorize exotic species as invasive; and other works consider them as invasive without any support for this characterization (Stampella 2015). An extreme example of this situation is the work by Rodolfo et al. (2008), who mention apepú as an invasive species in a tourist path within Iguaçu National Park (Paraná, Brazil) after finding a density of one apepú individual per linear kilometer.

Phytosanitary policies also represent a threat to the local diversity of citrus. In late 2009, a phytosanitary emergency was declared in the province due to the presence of HLB (Huanglongbing), a disease capable of devastating most citrus varieties (SENASA 2012). Due to the confirmation of several positive cases, the last few years have seen the removal of more than 1500 plant individuals in several departments in the north of Misiones province, as well as 21500 specimens in Paraguay (SENAVE 2013, TD 2014).

\section{History of tala and the talares (tala forests) in PCS and surroundings}

The most important forest community of Buenos Aires province, the talar, grows in the northeast of this province, along the coastal region from San Nicolás de los Arroyos in the north to Mar Chiquita in the south (Cabrera 1944, Parodi 1940, Torres Robles \& Arturi 2009). The talar woods are developed from the soils formed over the shell ridges existing in the area, with a parallel and sub-parallel arrangement to the coast, whose conformation was linked to the changes in sea level that occurred during the Holocene (Cavallotto 2009). This community is dominated by the tala, along with coronillo (Scutia buxifolia Reisseck), sombra de toro (Jodina rhombifolia (Hook. \& Arn.) Reissek.), and molle (Schinus longifolia (Lindl.) Speg.), among others. The characteristics of talar forests are conditioned by diverse variables such as substrate, climate, landscape structure and the type and intensity of anthropic management (Torres Robles \& Arturi 2009).

The anthropic use of talar forests has been studied from diverse disciplinary perspectives. Archaeological research has identified the occupation of these formations by late Holocene hunter-gatherer groups. The talar forest is considered to have been a key element in the choice of settlement sites because it provided refuge, protection and a multiplicity of resources (Aldazábal et al. 2004, González \& Frère 2009, Paleo et al. 2002). Archaeobotanical studies have allowed recognizing the use of $C$. tala in archaeological remains such as pottery fragments, mortars and pestles (Pérez Meroni et al. 2010) and coal (González \& Frère 2009). These human groups possibly did not cause major alterations to the talar forests or other plant communities (Delucchi \& Correa 1992).

Historical references point to the intensive use of the wood of this species since the beginnings of the Hispanic occupation of Buenos Aires in the 16th century (Athor 2006, Torres Robles \& Tur 2006), mainly as firewood and as material for building fences and houses. There were Town Hall ordinances aimed at protecting it from overexploitation. Numerous chroniclers, travelers and naturalists of the $18^{\text {th }}$ and $19^{\text {th }}$ centuries such as Cardiel, Falkner, Azara, Carrió de la Vandera, Armaignac and Morris, mention the presence and use of talar forests in the 
coast of the Río de la Plata (Athor 2006, Azara 1943, Cardiel 1930, Carrió de la Vandera 1997, Delucchi \& Charra 2012, Falkner 2003). Vervoorst (1967) mentions that in the 19th century, the tala and coronillo forests were exploited for firewood, timber, and coal. Since the late 19th century, their exploitation became even more intense due to their use as train fuel (González \& Frère 2009). Likewise, tala was also used for dyes, as medicine, food, and as raw material for diverse utensils (González \& Frère 2009, Hurrell 2004).

We will focus on the talar formations that grow on shell levees, due to the existence of the "Parque Costero del Sur" Biosphere Reserve (PCS), located in the coastal area of the departments Magdalena and Punta Indio. Palynological studies attest to the presence of this species in the area since approximately 2000 years BP (Paleo et al. 2002).

The establishment of PCS as a protected area is grounded on its rich biodiversity that includes talar forests, which are a conspicuous element of the local coastal environment, combined with grasslands, wetlands, and beaches. The identification of the valuable natural and cultural heritage of the area by the CEPA (Centro de Estudios $y$ Proyectación del Ambiente) foundation led to a proposal of protection for this area. Thus, in 1984 the PCS was declared as a Natural and Cultural World Biosphere Reserve by UNESCO (CEPA 1989). Furthermore, the PCS was declared as Refugio de Vida Silvestre (Wildlife Refuge) by the provincial government in 1997. It is worth noting that its protection was driven and decided "from the outside" without involving the local population, and that it existed on paper only for a long time. At local level, the Ordinance $N^{\circ} 294 / 98$ of Punta Indio bans the use of certain native plant species typical of talar forests such as tala, coronillo, sombra de toro, espinillo (Vachellia caven (Molina) Seigler \& Ebinger) and ombú (Phytolacca dioica L.). This regulation is often questioned by the local inhabitants who demand the right to use some of these native species, e.g., tala and coronillo, that are highly valued as firewood (Doumecq 2019, Doumecq et al. 2020).

The diverse economic activities that take place in the area and the indiscriminate logging that has persisted through time, have led to shrinkage of the talar forests, which are at present strongly altered (Torres Robles \& Arturi 2009). However, their persistence is probably explained by the benefits they provide for cattle, such as shade and shelter (Arturi et al. 2006). The locals express their concern about environmental issues and identify habitat exploitation as a local problem that is often attributed to the lack of control on the part of government officers (Stratta Fernández et al. 2017). On the other hand, the locals are also interested in the development of the area as a touristic area, which necessitates the development of the service sector to respond to that demand, while maintaining these activities compatible with the nature of a protected area.

Ethnobotanical studies have corroborated the appropriation of native flora, especially the tala, within the PCS. This is evidenced by the sustained consumption of the fruit as food and the novel use of the leaves to elaborate a typical beverage, a liquor that is sold to tourists in the craft stalls of Punta del Indio (Ghiani-Echenique et al. 2018): "We sell tala liquor, as a souvenir, when people come they always want to take a souvenir of the place they visited" (A.Z. 30 years old, female, Punta del Indio). With respect to its use as firewood, most local producers agree on the negative effects of overexploitation on talar forests, and consequently avoid cutting trees. However, the use of tala wood at domestic level persists in their practices and discourses without a negative connotation, whereas abusing this resource for wood is seen as strongly negative for the environment.

All this indicates that the tala is part of the identity of the people that inhabit the PCS, given that they identify, value, and use this species in their daily life. However, some local activities are non-sustainable or harmful for the environment and thus for the preservation of talar forests. These activities are currently controlled by regulations but, as stated by Arturi et al. (2006), it is necessary to integrate a management plan into the productive structure of the area, to guarantee the permanence and sustainable use of talar forests. In this sense, the park management committee promotes activities tending to the conservation of talar forests in general and tala trees in particular.

\section{Landscape construction according to its context}

The previous examples show that the native/exotic dichotomy is not operational, because it is not significant for the perspective of local inhabitants. Consequently, a conservation model guided by biocultural paradigm, as mentioned in the introduction, seems to be the most operative (Diegues 2000, Maffi 2001, Nazarea 2006). However, the paradigm of natural conservation, strongly present in the discourse and actions of managers, is the background for this dichotomy, in which native elements are an object for conservation while the exotic ones, considered as disruptive, must be eliminated (Rodolfo et al. 2008). Both peaches and citrus are identitary plants -and thus, part of the biocultural heritage- for the local people, with a well-documented local history, manifold uses, and widely 
spread in diverse microenvironments of domestic units (Hilgert et al. 2014, Stampella et al. 2013b); in the case of peaches, they are even promoted by local authorities as a symbol of the local alimentary heritage. Despite this, in the National Parks Iguazú and El Palmar, both citrus and peaches are considered exotic invasive plants (Management Plan for El Palmar National Park 2015, Stampella 2015).

The other side of the coin is the case of the tala, a native tree that has been overexploited by diverse sectors throughout history, while being a sustainable resource for local family-scale producers (Doumecq 2019). However, this alternative local usage generates conflict in the areas established as Multiple Use Reserve and even in entire departments (such as in Punta Indio) where the use of wood from this species is banned.

It is possible to reconsider these three examples from the perspective of a construction of the landscape, that is to say, an intervened environment built by past and present practices with diverse local meanings, in which native and introduced species are equally used by local inhabitants in their daily life, to construct this same environment (Paleo et al. 2016). Thus, we wonder if the paradigm of natural conservation could be re-focused with a biocultural approach.

For the case of citrus and peaches, fruit trees that have been introduced since the first contact between the Old and New Worlds, and are currently associated to Jesuit ruins and family-level producers, we pose the following questions: are these fruit trees not a cultural and historical heritage? In this case, would conservation in a strict biological-ecological sense, not threaten this heritage? Are these plants really invasive? Are the relationships that have existed between these citrus, and the local fauna for more than five centuries, taken into account before undertaking eradication procedures?

Similarly, though in an opposed direction, for the case of the talar forests: Is it only the natural heritage that which is being preserved? Are the diachronic relationships between talar forests and the different human populations taken into account? Considering the diverse uses of talar forests by local inhabitants, would it be possible to differentiate between sustainable and non-sustainable management practices?

These examples allow us to reflect on the importance of time in the construction and permanence of environmental lore. The concept of "traditional" has been defined in diverse works, generally as long-established knowledge that is transmitted from one generation to the next (Berkes 1993). Here, we also link the concept of "local" with the intervention on the environment -in this case, cultivated lands, and the peaches and citrus ethnovarieties-, in cases where, despite the relatively short time elapsed, this interaction has given rise to a corpus of currently valid knowledge that is used and renewed by each generation, allowing for sustainability of the cultivation and the practices related to these fruits as food choices, but also as elements with a high symbolic value that deserve an outstanding place in the discussion.

\section{Conclusions}

This contribution analyses three examples of tree species and their significance for both the local people and external agents, in different areas that receive protection because of their biological and cultural attributes, with national and international recognition. The perusal of these species as texts demonstrates that according to the local context- they are considered as a part of local identity or heritage no matter a long or short story and native or exotic origin. This characteristic in the three studied cases is further demonstrated by the existence of local labels to designate the plants and their fruit (Quebrada peaches, apepú -the Guarani name for bitter orange-), and even naming the forest communities generated by these plants and where diverse human populations have had settlements, such as the talares (talar forests). Likewise, in the three cases these plants are assigned uses that respond to local demands situated in time and space, in addition to those recognized globally.

In contrast, in another context and depending on the activity of external agents, the valuation of these plants is different. In areas that are natural reserves, where conservation assumes the preservation of "pristine" pre-existent environments, native species are given greater importance. In this case, while in Buenos Aires the tala and talar forests were the motive behind the creation of the protected area, in Misiones the apepú together with other citrus that result from local management are seen as a threat to native flora that should be exterminated. In the case of productive areas such as Humahuaca Ravine (UNESCO World Heritage Site since 2003) where this heritage is associated to tourist activity (Montenegro 2010), it is the added value which predominates: the particular features (flavor, size, specific uses) of the peaches are significant, and these crops do not compete with commercial varieties as in the case of the citrus trees in Misiones. 
Studies that approach these issues from ethnobotanical and applied botanical standpoints offer alternative views to characterize the new modes of relationship of peoples and individuals (Ladio et al. 2013, Pochettino 2007), including management strategies for spaces and species, as well as the elaboration of particular products and their inclusion in trade circuits different from conventional ones, and which respond to the demands for a local product with distinctive features. It is our hope that the knowledge generated from such scientific research may translate into benefits for current society as a whole and especially for the local communities involved.

List of abbreviations: BP: Before Present; CEPA: Centro de Estudios y Proyectación del Ambiente; CONICET: Consejo Nacional de Investigaciones Científicas y Técnicas; FCNyM: Facultad de Ciencias Naturales y Museo, Universidad Nacional de La Plata; Fig.: Figure; FONCyT: Fondo Nacional para la Ciencia y la Tecnología; INECOA: Instituto de Ecorregiones Andinas; LEBA: Laboratorio de Etnobotánica y Botánica Aplicada; NEA: Argentine Northeast; PCS: Parque Costero del Sur; UNESCO: United Nations Educational, Scientific and Cultural Organization; UNJu: Universidad Nacional de Jujuy, Argentina; UNLP: Universidad Nacional de La Plata, Argentina

Ethics approval and consent to participate: We have previously informed consent, as detailed in the manuscript. An agreement of will was established between the interviewees and the researchers, where the framework in which the work is carried out, the objectives and importance of the research and the commitment to deliver a copy of the work carried out to the families interviewed and not to use the information provided for commercial purposes. On the other hand, the interviewee explicitly agrees to participate in conducting the interview and chooses as to the possibility of spreading his name, photos, recordings and/or knowledge.

Availability of data and materials: All the materials were deposited in the ethnobotanical collections of LEBA and INECOA (UNJU-CONICET)

Competing interests: There are no conflicts of interest.

Funding: Field work was financially supported by Universidad Nacional de La Plata, Universidad Nacional de Jujuy, Consejo Nacional de Investigaciones Científicas y Técnicas (CONICET) and Fondo Nacional para la Ciencia y la Tecnología (FONCyT: PICT 2015-1548).

Authors' contributions: Doumecq MB: elaboration of research questions and interviews. Field work, analysis of the results, preparation of tables and graphs, writing of the manuscript. Lambaré A: elaboration of research questions and interviews. Field work, analysis of the results, preparation of tables and graphs, writing of the manuscript. Stampella PC: elaboration of research questions and interviews. Field work, analysis of the results, preparation of tables and graphs, writing of the manuscript.

\section{Acknowledgments}

We especially acknowledge all those people who shared their time and wisdom and consent in the publication. We would like to also thank the help and cooperation of our thesis directors: Drs. María Lelia Pochettino, Norma Hilgert, Nilda D. Vignale, Patricia Arenas and Julio Hurrell, and Dr. Cecilia Morgan's review of the English version of this manuscript. Field work was financially supported by Universidad Nacional de La Plata, Universidad Nacional de Jujuy, Consejo Nacional de Investigaciones Científicas y Técnicas (CONICET) and Fondo Nacional para la Ciencia y la Tecnología (FONCyT: PICT 2015-1548).

\section{Literature cited}

Alcorn J. 1995. The scope and aims of ethnobotany in a developing world. In Ethnobotany. Evolution of a discipline. Edited by RE Schultes \& S von Reis. Dioscorides Press, Portland, USA, Pp. 23-39.

Aldazábal V, Weiler N, Eugenio E. 2004. Una perspectiva geoarqueológica para comprender la ocupación humana en la costa central de la provincia de Buenos Aires. Intersecciones en Antropología 5:29-38.

Arturi M, Pérez C, Horlent M, Goya JF, Torres Robles S. 2006. El manejo de los talares de Magdalena y Punta Indio como estrategia para su conservación. In Talares Bonaerenses y su Conservación. Edited by E Mérida \& J Athor. Fundación de Historia Natural Félix de Azara, Buenos Aires, Argentina, Pp. 35-45.

Arturi M, Pérez Meroni M, Paleo C, Herrera R. 2009. Lineamientos para una zonificación del Parque Costero del Sur basada en la relación del paisaje con la cultura. In Parque Costero del Sur. Naturaleza, conservación y patrimonio cultural. Edited by J Athor. Fundación de Historia Natural Félix de Azara, Buenos Aires, Argentina, Pp. 18-36.

Athor J. 2006. Referencias bibliográficas históricas que delatan la presencia del talar en la ciudad de Buenos Aires. In Talares bonaerenses y su conservación. Edited by E Mérida \& J Athor. Fundación de Historia Natural Félix de Azara, Buenos Aires, Argentina, Pp. 218-222.

Azara F. 1943. Descripción e Historia del Paraguay y del Río de la Plata. Editorial Bajel, Buenos Aires, Argentina. 
Báez JR. 1947. La primera colonia agrohispana en el Tucumán (Siglo XVI). Revista Argentina de Agronomía 14(2):8593.

Báez JR. 1949. Breves apuntes sobre la migración de las plantas agrícolas euro-indianas en el momento del descubrimiento. Lilloa 18:33-36.

Banfi A. 1954. Difusión de buenas variedades cítricas. IDIA 90-92:102.

Berkes F. 1993. Traditional ecological knowledge in perspective. In Traditional ecological knowledge: Concepts and cases. Edited by JT Inglis. International Development Research Centre, Ottawa, Canada, Pp. 1-9.

Brabo FJ. 1872. Colección de documentos relativos á la expulsión de los jesuitas de la República Argentina y del Paraguay. Establecimiento Tipográfico de JM Pérez, Madrid, Spain.

Burger P, Terral J-F, Ruas M-P, Ivorra S, Picq S. 2011. Assessing past agrobiodiversity of Prunus avium L. (Rosaceae): a morphometric approach focussed on the stones from the archaeological site Hôtel-Dieu (16th century, Tours, France). Vegetation History and Archaeobotany 20(5):447-458.

Burkart A. 1972. El "durazno de palo" de Córdoba, Prunus persica (L.) Batsch var. aposarca, nueva variedad y notas sobre el sistema de esta especie. Darwiniana 17:443-457.

Cabrera AL. 1944. Los árboles indígenas de la Provincia de Buenos Aires. Boletín de Agricultura Ganadería e Industrias 29(5-6):15-18.

Cabrera AL. 1971. Fitogeografía de la República Argentina. Boletín de la Sociedad Argentina de Botánica 14(1-2):142.

Cabrera AL, Willink A. 1980. Biogeografía de América Latina. 2nd ed., Monografía 13, serie Biología. Secretaría General de la Organización de los Estados Americanos, Washington DC, USA.

Capparelli A, Lema V, Giovannetti M, Raffino R. 2005. Introduction of European crops (wheat, barley and peach) in Andean Argentina during the 16 th century: archaeobotanical and ethnohistorical evidence. Vegetation History and Archaeobotany 14:472-484.

Cardiel J. 1930 [1748]. Diario del viaje y misión al Río del Sauce realizado en 1748. Editorial Coni, Buenos Aires, Argentina.

Carrió de la Vandera A. 1997 [1773]. El Lazarillo de ciegos caminantes. Editorial Emecé, Buenos Aires, Argentina.

Casas A. 2001. Silvicultura y domesticación de plantas en Mesoamérica. In Plantas, cultura y sociedad. Estudio sobre la relación entre seres humanos y plantas en los albores del siglo XXI. Edited by B Rendón Aguilar, S Rebollar Domínguez, J Caballero Nieto \& MA Martínez Alfaro. Universidad Autónoma Metropolitana, México D.F., México, Pp. 123-157.

Cavallotto JL. 2009. Caracterización e historia evolutiva del sustrato sobre el que se desarrollan los talares del nordeste bonaerense. In Parque Costero del Sur. Naturaleza, conservación y patrimonio cultural. Edited by J Athor. Fundación de Historia Natural Félix de Azara, Buenos Aires, Argentina, Pp. 66-81.

CEPA (Centro de Estudios y Proyectos del Ambiente), 1989. Naturaleza y cultura pampeana en el mapa del mundo: Parque Costero del Sur. Ediciones Ambiente, La Plata, Argentina.

Cotton CM. 1998. Ethnobotany: Principles and applications. J. Wiley \& Sons., Chichester, U.K.

Delucchi G. 2011. Sinopsis de las especies de Rosaceae adventicias: subfamilia Prunoideae. Bonplandia 20:73-94.

Delucchi G, Charra GR. 2012. La flora y vegetación pampeanas vistas por los cronistas y viajeros de los siglos XVIII y XIX. Historia Natural, Tercera Serie 2(1):73-83.

Delucchi G, Correa R. 1992. Las especies vegetales amenazadas de la Provincia de Buenos Aires. In Situación ambiental de la Provincia de Buenos Aires. Recursos y Rasgos Naturales en la Evaluación Ambiental. Edited by HL López \& EP Tonni. Comisión de Investigaciones Científicas, La Plata, Argentina, Pp. 1-39.

Depypere L, Chaerle P, Vander Mijnsbrugge K, Goetghebeur P. 2007. Stony endocarp dimension and shape variation in Prunus section Prunus. Annals of Botany 100:1585-1597.

Diegues ACS. 2000. Conhecimento e manejo tradicionais: ciencia e biodiversidade. NUPAUB, São Paulo, Brasil. 
Doumecq MB. 2019. Evaluación etnobotánica de los recursos vegetales combustibles actuales y potenciales de la Ribera Platense (provincia de Buenos Aires, Argentina). PhD dissertation, Universidad Nacional de La Plata.

Doumecq MB, Petrucci NS, Stampella PC. 2020. Cuando los saberes no dialogan. Prácticas en conflicto en el Parque Costero Sur (Buenos Aires). Bonplandia 29(1):57-70.

Evans MI. 1993. Conservation by commercialization. In Tropical forests, people and food: biocultural interactions and applications to development. Edited by CM Hladik, A. Hladik, OF Linares, H Pagezy, A Semple \& M Hadley. UNESCO, Paris, France, Pp. 815-822.

Falkner T. 2003 [1774]. Descripción de Patagonia y de las partes contiguas de la América del Sur. Nueva Dimensión Argentina, Buenos Aires, Argentina.

Ferrari JB. 1646. Hesperides sive de malorum aureorum cultura et usu. Libri Quatuor, Sumptibus Hermanii Scheus, Roma, Italia.

Ghiani Echenique N, Doumecq MB, Pochettino ML. 2018. Saberes botánicos en el talar. Utilización de plantas silvestres con fines medicinales y alimenticios en el Parque Costero del Sur (partidos de Magdalena y Punta indio, Buenos Aires, República Argentina). Gaia Scientia 12(1):56-80.

Gmitter FG Hu X. 1990. The possible role of Yunnan, China, in the origin of contemporary citrus species (Rutaceae). Economic Botany 44(2):267-277.

González MI, Frère MM. 2009. Talares y paisaje fluvial bonaerense: arqueología del río Salado. Intersecciones en Antropología 10(2):249-265.

Harlan JR. 1992. Crops \& Man. 2nd edition, American Society of Agronomy, Inc., Madison, USA.

Hernández Bermejo JE, Lora González A. 1996. La documentación histórica y bibliográfica como fuente de información y evidencia etnobotánica. Monografías del Jardín Botánico de Córdoba 39-50.

Hilgert NI, Lambaré DA, Vignale ND, Stampella PC, Pochettino ML. 2014. ¿Especies naturalizadas o antropizadas? Apropiación local y la construcción de saberes sobre los frutales introducidos en época histórica en el norte de Argentina. Revista Biodiversidad Neotropical 4(2):69-87.

Hurrell JA. 2004. Árboles Rioplatenses. In Biota Rioplatense III. Edited by JA Hurrell \& HB Lahitte. $1^{\circ}$ ed. $1^{\circ}$ reimp. L.O.L.A., Buenos Aires, Argentina.

Hurrell JA, Stampella PC, Doumecq MB, Pochettino ML. 2019. Ethnoecology in pluricultural contexts: Theoretical and methodological contributions. In Methods and Techniques in Ethnobiology and Ethnoecology. Edited by UP albuquerque, RF Paiva Lucena, LVF Cruz da Cunha \&, RR Nóbrega Alves. Humana Press, New York, USA, Pp. 163186.

Hurrell JA, Ulibarri EA, Delucchi G, Pochettino ML. 2010. Frutas frescas, secas y preservadas. L.O.L.A., Buenos Aires, Argentina.

Ladio AH. 2005. Malezas exóticas comestibles y medicinales utilizadas en poblaciones del Noroeste patagónico: aspectos etnobotánicos y ecológicos. BLACPMA 4(4):75-80.

Ladio AH, Molares S, Ochoa JJ, Cardoso B. 2013. Etnobotánica aplicada en Patagonia: la comercialización de malezas de uso comestible y medicinal en una feria urbana de S.C. de Bariloche (Río Negro, Argentina). BLACPMA 12(1):2437.

Laird SA, Noejovich F. 2002. Construyendo relaciones de investigación equitativas con pueblos indígenas y comunidades locales: consentimiento previamente informado y acuerdos de investigación. In Biodiversidad y conocimiento tradicional. Participación equitativa en práctica. Edited by SA Laird. Nordan Comunidad, Montevideo, Uruguay, Pp. 205-244.

Lambaré DA. 2014. Manejo de variedades locales de Prunus persica (Rosaceae) en la Quebrada de Humahuaca, Argentina y su relación con los sistemas agrícolas tradicionales. Zonas Áridas 15(1):128-147.

Lambaré DA. 2015. Procesos locales de selección cultural en poblaciones de frutales de la familia Rosaceae originarias del Viejo Mundo utilizadas por comunidades rurales del noroeste argentino. PhD dissertation, Universidad Nacional de La Plata. 
Lambaré DA, Pochettino ML. 2012. Diversidad local y prácticas agrícolas asociadas al cultivo tradicional de duraznos Prunus persica (Rosaceae), en el Noroeste de Argentina. Darwiniana 50(2):174-186.

Lambaré DA, Vignale ND, Pochettino ML. 2015. Las ferias y festivales regionales como instancia de reafirmación del patrimonio biocultural en la Quebrada de Humahuaca (Jujuy, Argentina): El intercambio de duraznos (Prunus persica). GAIA Scientia 9:1-9.

Lorandi AM. 1988. El servicio personal como agente de desestructuración en el Tucumán colonial. Revista Andina 6(1):135-173.

Maffi L. 2001. Introduction. On the interdependence of biological and cultural diversity. In On biocultural diversity. Linking language, knowledge, and the environment. Edited by L. Maffi. Smithsonian Institution Press, Washington, Pp. 1-50.

Martínez GJ, Manzano-García J. 2016. Estilos de percepción de la biodiversidad y su conservación en actores sociales de áreas protegidas de Córdoba. Revista del Museo de Antropología 9(2):135-152.

Martínez-Crovetto R. 1963. Esquema Fitogeográfico de la provincia de Misiones (República Argentina). Bonplandia 1(3):171-223.

Medeiros MFT. 2010. Historical ethnobotany: an approach through historical documents and their implications nowadays. In Recent developments and case study in ethnobotany Edited by UP Albuquerque \& $\mathrm{N}$ Hanazaki. NUPEEA, Recife, Brasil, Pp. 127-142.

Medeiros PM, Ferreira JWS, Ramos MA, Silva TC, Ladio AH, Albuquerque UP. 2017. Why do people use exotic plants in their local medical systems? A systematic review based on Brazilian local communities. PLoS ONE 12:1-14.

Montenegro M. 2010. El patrimonio arqueológico de Jujuy: miradas diversas desde la escuela. Estudios Sociales del NOA 11:107-121.

Nazarea VD. 2006. Local knowledge and memory in biodiversity conservation. Annual Review of Anthropology 35:317-335.

Palacios J. 1978. Citricultura Moderna. Hemisferio Sur, Buenos Aires, Argentina.

Paleo MC, García Lerena MS, Stampella PC, Doumecq MB, Pochettino ML. 2016. La construcción del paisaje del litoral rioplatense. 2. Las estancias y sus árboles. Editorial Universitaria de La Plata, La Plata, Argentina.

Paleo MC, Páez MM, Pérez Meroni M. 2002. Condiciones ambientales y ocupación humana durante el Holoceno tardío en el litoral fluvial bonaerense. In Del Mar a los Salitrales. Edited by D Mazzanti, M Berón \& F Oliva. Universidad Nacional de Mar del Plata, Mar del Plata, Argentina, Pp. 365-376.

Parodi LR. 1940. Distribución geográfica de los talares de la Provincia de Buenos Aires. Darwiniana 4: 33-56.

Pedersen TM. 1995. Especies de plantas vasculares introducidas y naturalizadas en el Noroeste Correntino. Anales de la Academia Nacional de Agronomía y Veterinaria 49:11-17.

Pérez Meroni M, Paleo MC, Pochettino ML, Lema VS. 2010. Procesamiento y consumo de vegetales por grupos cazadores-recolectores del Holoceno tardío, en los partidos de Magdalena y Punta Indio, provincia de Buenos Aires. In Mamül Mapu: Pasado y presente desde la arqueología pampeana. Edited by M Berón, L Luna, M Bonomo, Cl Montalvo, CM Aranda \& M Carrera Aispitarte. Editorial Libros del Espinillo, Ayacucho, Argentina, Pp. 215-226.

Plan de Gestión PN El Palmar. Management Plan for El Palmar National Park. Administración de Parques Nacionales [online]. 2015. https://sib.gob.ar/archivos/Plan_de_Gestion_El_Palmar_Doc_Final.pdf (Accessed 30 April 2021).

Pochettino ML. 2007. Recolección y comercialización de plantas silvestres en dos comunidades Mbya-Guarani (Misiones, Argentina). Kurtziana 33:217-226.

Ramón-Laca L. 2003. The introduction of cultivated citrus to Europe via Northern Africa and the Iberian Peninsula. Economic Botany 57(4):502-514.

Rivera-Núñez D, Obón de Castro C, Ríos-Ruiz S, Fernández CS, Méndez-Colmenero F, Verde-López A, CanoTrigueros F. 1997. Las variedades tradicionales de frutales de la cuenca del Río Segura. DM Librero Editor, Murcia, Spain. 
Rodolfo AM, Cândido JF, Godinho Temponi L, Zanin Gregorini M., 2008. Citrus aurantium L. (laranja-apepu) e Hovenia dulcis Thunb. (uva-do-japão): espécies exóticas invasoras da trilha do Poço Preto no Parque Nacional do Iguaçu, Paraná, Brasil. Revista Brasileira de Biociências 6(1):16-18.

Scorza R, Sherman WB. 1996. Peaches. In Methods in fruit breeding. Edited by J Janick \& JR Moore. Purdue University Press, Madison, USA, Pp. 325-440.

SENASA (Servicio Nacional de Sanidad y Calidad Agroalimentaria). Informe HLB [online]. 2012. http://viejaweb.senasa.gov.ar/Archivos/File/File3511-Informe_HLB_2012.pdf (Accessed 23 May 2021).

SENAVE (Servicio Nacional de Calidad y Sanidad Vegetal y de Semillas). HLB: ya se eliminaron 21500 plantas infectadas [online]. 2013. http://www.senave.gov.py/noticias-57-SENAVE-HLB-Ya-seeliminaron-21500-plantasinfectadas.html (Accessed 12 May 2021).

Seo MN, Xifreda C. 2008. Rutaceae. In Flora Fanerogámica Argentina. Edited by AM Anton \& FO Zuloaga. von Düring, Córdoba, Argentina, Pp. 1-22.

Sica G. 2006. Del pucará al pueblo de indios. El proceso de construcción de la sociedad indígena colonial en la jurisdicción de San Salvador de Jujuy (Noroeste de Argentina), siglo XVII. PhD dissertation. Universidad de Sevilla.

Sica G. 2010. Del tráfico caravanero a la arriería colonial indígena en Jujuy. Siglos XVII y XVIII. Revista Transporte y Territorio 3:23-39.

Sica G, Bovi M, Mallagray L. 2010. La quebrada de Humahuaca: de la colonia a la actualidad. In Jujuy en la historia de la colonia al siglo XX. Edited by A Teruel \& M Lagos. Universidad Nacional de Jujuy, San Salvador de Jujuy, Argentina, Pp. 351-372.

Sica G, Ulloa M. 2010. Jujuy en la colonia. De la fundación de la ciudad a la crisis del orden colonial. In Jujuy en la historia de la colonia al siglo XX. Edited by A Teruel \& M Lagos. Universidad Nacional de Jujuy, San Salvador de Jujuy, Argentina, Pp. 41-85.

Stampella PC. 2015. Historia local de los cítricos (Citrus L., Rutaceae) del viejo mundo asilvestrados en el corredor de las antiguas misiones jesuíticas de la provincia de misiones (Argentina). Caracterización desde una perspectiva interdisciplinaria. PhD dissertation. Universidad Nacional de La Plata.

Stampella PC. 2016. Local variability of citrus (Citrus L., Rutaceae) in pluricultural enclaves in the South of Misiones (Argentina): Diversity, uses and perception, and classification of variability. Journal of Ethnobiology 36(3):637-657.

Stampella PC. 2018. Variabilidad local de cítricos (Citrus, Rutaceae) en enclaves pluriculturales en el sur de Misiones (Argentina): microambientes y prácticas de manejo. Boletín de la Sociedad Argentina de Botánica 53(1):135-150.

Stampella PC, Delucchi G, Pochettino ML. 2013a. Naturalización e identidad del "limón mandarina", Citrus × taitensis (Rutaceae, Aurantioideae) en la Argentina. Boletín de la Sociedad Argentina de Botánica 48(1):161-169.

Stampella PC, Delucchi G, Keller HA, Hurrell JA. 2014. Etnobotánica de Citrus reticulata (Rutaceae, Aurantioideae) naturalizada en la Argentina. Bonplandia 23(2):151-162.

Stampella PC, Lambaré DA, Hilgert NI, Pochettino ML. 2013b. What the iberic conquest bequeated to us: the fruit trees introduced in argentine subtropic, their history and importance in present traditional medicine. EvidenceBased Complementary and Alternative Medicine Article ID 868394, 17 pp.

Stratta Fernández R, Ríos Carmenado I, López González M, 2017. Desarrollo de competencias para la gestión de proyectos de desarrollo rural a través de grupos de acción local: la experiencia de Punta Indio (Argentina). In International Development. Edited by S. Appiah-Opoku. Intech, Rijeka, Croatia, Pp. 153-172.

Taylor SJ, Bogdan R, DeVault M. 2016. Introduction to Qualitative Research Methods: A Guidebook and Resource, $4^{\text {th }}$ Edition. JohnWiley \& Sons, Inc., Hoboken, USA.

TD (Territorio Digital). Alerta por la confirmación de 44 nuevos casos de HLB en Misiones [online]. 2014. http://territoriodigital.com/notaimpresa.aspx?c=2334528304986364 (Accessed 28 May 2021).

Torres Robles SS, Arturi M. 2009. Variación de la composición y riqueza florística en los talares del Parque Costero del Sur y su relación con el resto de los talares bonaerenses. In Parque Costero del Sur. Naturaleza, conservación y 
patrimonio cultural. Edited by J Athor. Fundación de Historia Natural Félix de Azara, Buenos Aires, Argentina, Pp. 104-121.

Torres Robles SS, Tur N. 2006. Los talares de la provincia de Buenos Aires. In La situación ambiental argentina 2005. Edited by A Brown, U Martínez Ortíz, M Acerbi \& JF Corcuera. Fundación Vida Silvestre Argentina, Buenos Aires, Argentina, Pp. 246-250.

Touwaide A. 2010. History of botany as ethnobotany. Proposals toward a new approach to the ancient legacy. In Tradiciones \& Transformaciones en Etnobotánica. Edited by ML Pochettino, AH Ladio \& PM Arenas. CYTED, San Salvador de Jujuy, Argentina, Pp. 55-63.

Vervoorst F. 1967. Las comunidades vegetales de la depresión del Salado. Serie fitogeográfica 7, SEAGN-INTA, Buenos Aires, Argentina.

Villalba MS, Lambaré DA. 2019. Las manzanas en Ocumazo (Jujuy, Argentina) como parte de la diversidad de cultivos tradicionales: usos y percepciones. Boletín de la Sociedad Argentina de Botánica 54:431-449. 